\title{
Investigación \\ Acerca de la crisis del conocimiento histórico y del mercado de los bienes culturales
}

José Carlos Bermejo Barrera

Catedrático. Departamento de Historia I. Universidad de Santiago de Compostela

\section{Resumen}

Se recogen en este artículo dos textos originalmente elaborados de manera independiente.

El primero de ellos, "Sobre el buen uso de los monumentos arqueológicos", publicado por primera vez en la revista Genon, parte del análisis de la situación actual del conocimiento histórico, fundamentalmente a través de tres argumentos principales: la transformación del monumento arqueológico en mercancía, la integración de éste en la industria expositiva y su banalización, que al final deriva en objeto de consumo turístico. Por otro lado, en el segundo texto, se desarrolla la contribución del patrimonio cultural a la economía política, sosteniendo una postura crítica para la que no existe un mercado de bienes culturales.

\section{Palabras clave}

\section{Memoria}

Historia

Conocimiento histórico

Monumentos

Bienes culturales

Economía

Mercados

Turismo cultural

Valoración

\section{Sobre el buen uso de los monumentos arqueológicos}

A partir del siglo XIX las sociedades occidentales comenzaron a establecer una serie de normas que tienen como fin conservar y proteger los restos materiales del pasado, que, en grandes líneas, pueden ser catalogados, o bien como documentos -si se trata de un objeto que contiene un texto-, o bien como monumentos -si se trata de construcciones de distinto tipo, o de todo tipo de objetos sin más.

La identificación de esos grupos de objetos con el pasado del Estado-nación hizo que ese mismo Estado les diese un estatuto jurídico más o menos desarrollado, que los fue definiendo bajo el concepto de patrimonio nacional. Por esa razón cuando se habla de su buen uso podría parecer, a primera vista, que de lo que se trataría es de considerar los aspectos jurídicos de su tratamiento. Sin embargo no será éste nuestro propósito, sino que lo que intentaremos será más bien definir los componentes ideológicos, es decir, el conjunto de ideas que en el momento presente gravitan en torno a la consideración social de los monumentos del pasado.

Dentro de este tipo de monumentos diferenciaremos a los monumentos artísticos, que se caracterizan -aparte de por poseer un valor estético intrínseco- por poder ser reutilizados y disfrutados en el presente, de los monumentos arqueológicos, que normalmente se presentan bajo la forma de fragmentos, que además carecen de un uso práctico -como el que puede seguir teniendo una iglesia románica-, y que pueden, o no, tener un valor estético, lo cual será meramente accidental en su consideración como material para estudiar por parte de los arqueólogos.

Este ensayo debe ser considerado como un fragmento de una genealogía del tiempo presente, y en ese proyecto genealógico ocupará un lugar privilegiado el análisis de la función que la memoria desempeña en la configuración de las sociedades occidentales; por ello será preciso comenzar por la primera de nuestras tesis.

El monumento arqueológico ha llegado a convertirse en una mera imagen

Una de las características diferenciales entre la especie humana y otras especies de animales que le son afines es el uso del lenguaje. La existencia de las diferentes lenguas es lo que ha permitido el desarrollo de formas de organización social complejas, y por ello se puede afirmar que toda sociedad puede definirse, además de por un conjunto de relaciones que diferentes personas desarrollan entre sí, como un sistema de comunicación.

Los sistemas sociales de comunicación son inseparables de los haces de relaciones sociales que los hacen posibles, y a las que a su vez configuran, pero también dependen de los medios que puedan utilizarse para desarrollar esa comunicación. En ese sen- 


\section{Investigación \\ Acerca de la crisis del conocimiento histórico y del mercado de los bienes culturales \\ José C. Bermejo Barrera}

tido podríamos distinguir, a grandes rasgos, tres grandes sistemas de comunicación desarrollados por las sociedades humanas: la comunicación verbal, la comunicación escrita, y la comunicación a través de las imágenes.

Cada uno de estos sistemas de comunicación lleva asociada una forma de configuración de la memoria colectiva, y por lo tanto una forma de establecer la relación con el pasado. En las sociedades orales, en las que la memoria desempeña un papel fundamental en la transmisión de la información, el pasado aparece configurado miticamente. En dichas sociedades suele establecerse una distinción entre dos tiempos pasados: el pasado próximo, al que podemos tener acceso a través de la memoria genealógica -que es fundamental para el mantenimiento de las estructuras elementales del parentesco-, y el pasado lejano, que se caracteriza por ser estático y carecer de profundidad. Estamos en el tiempo del sueño de los indigenas australianos, o en el tiempo de los origenes en el que tuvieron lugar una serie de acontecimientos que dieron lugar al tiempo presente a través de los mitos de instauración de las diferentes instituciones que definen nuestra cultura. Entre el tiempo de los antepasados y el tiempo presente no hay solución de continuidad. No puede pasarse suavemente de uno a otro, como ocurre con el tiempo histórico. Si volviese el tiempo del sueño el mundo se retrotraería a sus condiciones iniciales y el orden en el que se sustenta la sociedad actual sería puesto en cuestión.

En ese tipo de sociedades no es posible pensar el pasado humano, ya que es imposible pensar la alteridad. Existe una forma de organizar la sociedad, que es la nuestra, que tiene sus origenes en las historias narradas por el mito. Las sociedades contemporáneas a la nuestra únicamente pueden ser concebidas como humanas en tanto que se nos asemejen, y no hay, propiamente hablando, sociedades del pasado, porque el pasado no existe: o bien es un aspecto del presente, o bien corresponde al tiempo de los origenes. En ese sentido si una de esas sociedades se encuentra con monumentos que sean obra de otras culturas que la hayan precedido en el tiempo tendrá que asimilarlos a través del uso -y por lo tanto negarles su estatuto de monumentos del pasado- o bien mitificarlos, remitiéndolos al tiempo de los origenes, y otorgándoles un significado simbólico dentro del conjunto de sus creencias, lo cual viene a ser otra forma de asimilación. El uso ideológico -y consecuentemente el uso social de los monumentos arqueológicos- por parte de esas sociedades vendrá determinado por este conjunto de coordenadas.

A partir del momento en el que comenzaron a desarrollarse los sistemas de escritura se dio una transformación radical de la memoria, tanto a nivel individual como colectivo. El texto contiene una información que se puede conservar a lo largo del tiempo, en tanto que perdure su soporte, y que hace posible nuevas formas de organización social, en tanto que la acumulación de información hace igualmente posible la acumulación de rique- zas -y consecuentemente del control de las relaciones sociales que las generan. El estudio de esas transformaciones sociales es el tema característico de la historia antigua, y no vamos a entrar en él aquí. Lo que sí nos interesa, por el contrario, es el hecho de que el texto puede transmitir información a través del tiempo. Una inscripción sobre una tumba, una estela que conmemora la victoria de un rey nos proporcionan información acerca del pasado. Y ese pasado podrá ser el de nuestra propia cultura, al igual que ocurría con la memoria genealógica, o bien el de otra cultura ajena.

No puede afirmarse que simplemente porque pervivan los textos del pasado ya vaya a surgir la historia, puesto que en el mundo griego la historia en sus origenes es básicamente historia contemporánea y se hace prácticamente sin textos. Pero si es cierto que esa es una condición de posibilidad que podría permitir el nacimiento del conocimiento histórico, una vez que se haya superado la concepción del pasado y de la memoria característica de las culturas orales.

Esta superación será únicamente gradual, puesto que si centramos nuestra atención en el próximo oriente antiguo, en el que sí se disponen de textos escritos provenientes del pasado, veremos que, tanto en Egipto como en Mesopotamia, los monumentos del pasado -tumbas templos, palacios- están totalmente integrados en la cultura del presente, porque son los monumentos de nuestros antepasados, de los que descendemos genealógicamente. Lo que estas culturas no fueron capaces de concebir fue un monumento del pasado de una cultura diferente a la nuestra, y ello a pesar de la existencia de la diversidad de lenguas, como el sumerio y el acadio, y del hecho de que alguna de esas lenguas -como el sumeriollegara a poseer la categoría de lengua muerta.

Los monumentos de nuestros antepasados pueden servir como acicate para la reflexión sobre la caducidad de las cosas humanas o para pronunciar un lamento sobre la gloria perdida de los tiempos de antaño, pero en modo alguno para pensar el pasado como una sucesión de sociedades y culturas diferentes a la nuestra, pero a las que la nuestra debe su origen. Esa concepción del pasado sólo llegará a ser posible -a través de un conjunto de avatares en los que no podremos detenernos- al llegar a la Europa del siglo XIX, en la que tiene lugar la instauración de la historia como disciplina, o como ciencia.

Pero el camino hasta ahi no fue en modo alguno un camino fácil, puesto que el Estado-nación, otro producto de la Europa del siglo XIX, va a mantenerse en una tensión dialéctica entre dos concepciones del pasado, que podriamos Ilamar la concepción comunitarista y la concepción historicista.

Por la primera de ellas la nación se define como una comunidad imaginaria, y por lo tanto tiende a concebir el tiempo histórico como 
1 y 2. El texto puede transmitir información a través del tiempo. Una inscripción sobre una tumba, una estela que conmemora la victoria de un rey nos proporcionan información acerca del pasado. Y ese pasado podrá ser el de nuestra propia cultura, al igual que ocurría con la memoria genealógica, o bien el de otra cultura ajena

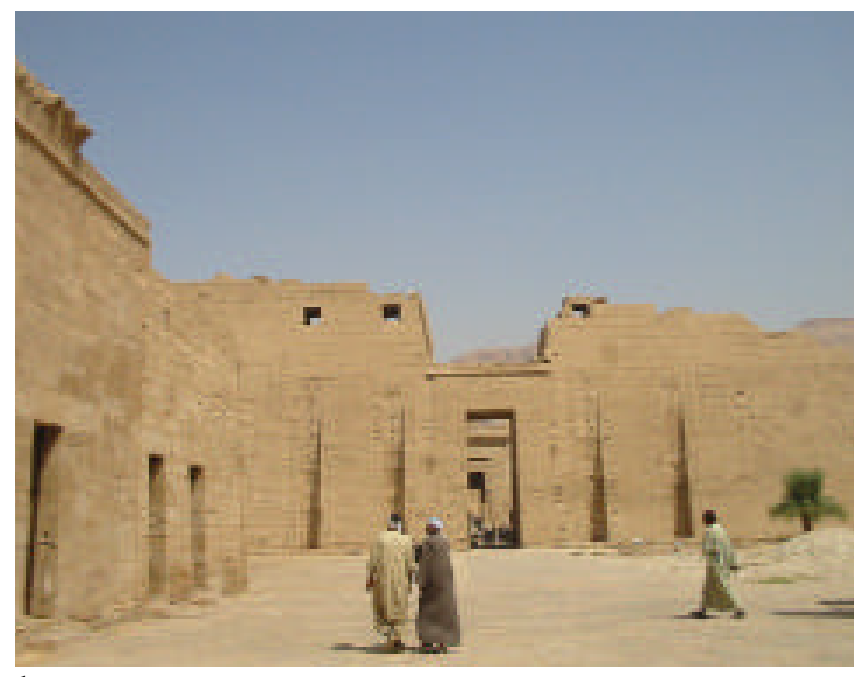

memoria familiar, como memoria de los antepasados, y en ese sentido hace que perdure imaginariamente la concepción de la memoria genealógica característica de las culturas orales. Naturalmente que se trata únicamente de una ficción, ya que la memoria genealógica es relativamente corta, mientras que ahora las naciones remiten su pasado a miles de años, pero esa ficción cumple una misión política. Al definir a la nación como comunidad se intentan reforzar los lazos sociales, debilitados por el desarrollo de la revolución industrial, y se intenta controlar la conducta de los ciudadanos mediante el establecimiento de una serie de obligaciones: fiscales, militares, civiles... que el nacimiento del individualismo contemporáneo puede hacer difícil de concebir.

En esa concepción del pasado y la memoria el monumento arqueológico asume el papel simbólico de ser un resto del mundo de nuestros antepasados. Del mismo modo que en la Edad Media se coleccionaban reliquias de los cuerpos de los santos, porque ponían a la gente en relación con lo sagrado y consecuentemente conferían prestigio, ahora, a partir del siglo XIX, el pasado de la nación se encarna en sus monumentos arqueológicos y artísticos, que vienen a ser una manifestación de su gloria.

Paralelamente a esa construcción del pasado tenemos la que hemos Ilamado la visión historicista. Esta visión, que no es totalmente incompatible con la anterior, se caracteriza por su relativismo. En ella se parte del principio de que es posible que haya diferentes formas de organizar las sociedades y diferentes visiones del mundo. Todas ellas serían igualmente válidas, pero, eso sí, cada una en su contexto histórico determinado. El conocimiento histórico no sirve básicamente para recrearnos narcisisticamente en la imagen de unos antepasados que serían similares a nosotros mismos, sino que, por el contrario, serviría como una lección de humildad, en tanto que relativiza nuestros valores y nuestras for-

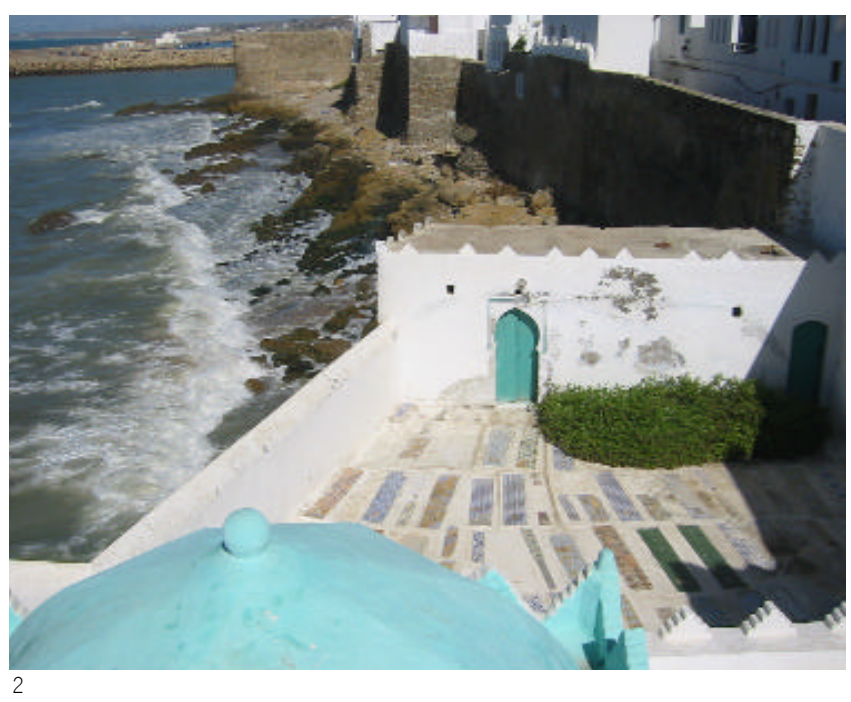

mas de organización social y nos hace ver que en el mismo marco geográfico en el que estamos se pudo haber vivido de formas diferentes, y lo que es más, que hay otra gran variedad de marcos geográficos totalmente ajenos al nuestro en los que esa variedad de formas de vida humana ha proliferado copiosamente.

El monumento arqueológico es en esa concepción algo que nos saca de nuestro mundo, nos obliga a realizar un esfuerzo imaginativo y nos lleva a intentar concebir otras sociedades diferentes. El monumento arqueológico, y a ello contribuye en buena medida su carácter fragmentario, es bueno para pensar. Nuestro acercamiento a él será imposible sin un esfuerzo intelectual que nos lleve a la lectura de otros textos del pasado, a la comparación entre unos monumentos y otros. El monumento arqueológico no puede ser comprendido de forma inmediata y de un modo directo, sino a través de un trabajo histórico, que sólo puede tener sentido en una sociedad que haya institucionalizado el conocimiento histórico en la educación y en la que esté presente a través de los medios de comunicación social, básicamente escritos.

Esta visión historicista del pasado, en tensión dialéctica con la visión más estrictamente nacionalista fue característica de la Europa del siglo XIX y de la primera parte del XX. Pero, a partir de mediados del siglo XX, se produjo un cambio en los sistemas de comunicación social del mundo occidental que traería consigo necesariamente una modificación del funcionamiento de la memoria colectiva, y consecuentemente de la consideración de los monumentos.

Con el desarrollo de los sistemas de comunicación de masas -radio, cine, televisión- y el desarrollo de los procesos de globalización de la economía, la política y las relaciones sociales, que tendrán lugar a partir de la Segunda Guerra Mundial, vino a producirse una transformación muy importante de nuestro panorama. 


\section{Investigación \\ Acerca de la crisis del \\ conocimiento histórico y \\ del mercado de los bienes \\ culturales \\ José C. Bermejo Barrera}

La radio, el cine y la televisión han supuesto, por una parte, el retorno de la oralidad y el desplazamiento de la escritura, con todo lo que ello supone de cambios en el lenguaje. El lenguaje oral, como es sabido, es mucho menos elaborado que el lenguaje escrito. En él las construcciones sintácticas son mucho más débiles y el hecho de que sea muchas veces el contexto lo que otorga significado a un enunciado, o, lo que es lo mismo, el predominio de los aspectos pragmáticos sobre los sintácticos trae consigo que se impongan formas mucho más sencillas del uso de la lengua.

Y no sólo eso sino que el cine y la televisión, al poder captar el valor de los gestos y de las imágenes en general crean un nuevo sistema de comunicación que por una parte se caracteriza por poseer una dimensión cosmopolita, pero que por otra parte, en tanto que vuelve a lo oral y a lo simbólico, retoma formas de la vida comunal, razón por la cual McLuhan lo definió utilizando el término de aldea global.

Pero en esos sistemas de comunicación los aspectos comunitarios -a los que también recurría la ideología nacionalista- son meramente imaginarios, puesto que los medios de comunicación de masas están controlados por unas pocas industrias (lo que es evidente en el caso del cine y la televisión), con lo que en la sociedad contemporánea el individuo se queda aislado frente a ellos, y no integrado en un sistema de comunicación comunitario, tal y como ocurría en las culturas orales. Los medios de comunicación de masas son casi omnipotentes, el espectador se encuentra alienado frente a ellos, que le ofrecen una proliferación de imágenes y mensajes verbales.

Es en esa proliferación -evidente en el momento actual en el que disponemos de cientos de canales de televisión- en donde reside una de las claves de los sistemas de comunicación de las sociedades desarrolladas actuales.

El mundo presente es un mundo claramente globalizado, tanto a nivel ecológico (por la contaminación a escala planetaria), como económico, social y político. El mundo genera una masa increible de información, que sería absolutamente indigerible. Los medios de comunicación -escrita y audiovisual- filtran esa información y nos ofrecen cada dia un conjunto de noticias que se supone que constituyen la realidad histórica presente. Pero en esas noticias el flujo de información es tan acelerado que los acontecimientos salen a la superficie para sumergirse rápidamente de nuevo en las profundidades del olvido.

Tenemos una capacidad limitada de asimilar información. Por eso cada día es preciso seleccionar algunos acontecimientos. Pero el criterio con el que se seleccionan tampoco es inocente. Son los intereses estratégicos, económicos y políticos en general los que hacen que un pais o una población sean noticia. La mayor parte de los países y de las personas no son noticia nunca. Únicamen- te unas pocas conseguirán salir a la luz cada día, pero para caer de nuevo en el olvido. Y es que otra de las características de los medios de información actuales es que la información se gasta rápidamente. Una noticia alcanza su máximo interés en el momento inicial, por ejemplo el inicio de un conflicto bélico, pero con el paso del tiempo ese conflicto pasa a formar parte de lo cotidiano y consecuentemente pierde su interés.

Tenemos, pues, dos mundos, el de lo cotidiano, qué no es objeto de atención, y el de lo interesante, que sí lo es. Lo interesante se caracteriza por conocer un único tiempo verbal, que es el presente, porque la información siempre tiene que ser actualidad. En ese sentido parece fácil comprender que en este sistema de comunicación es muy difícil que se desarrolle una auténtica memoria colectiva. La memoria únicamente funcionará a un plazo muy corto cuando se busquen los precedentes de un acontecimiento, pero los precedentes no son en modo alguno la historia, que será ahora claramente cuestionada.

Si puede hablarse en el momento presente de una cierta crisis del conocimiento histórico ello es debido a dos razones. En primer lugar a que la identificación de la historia con el Estadonación en los siglos XIX y XX hace que esa disciplina pueda verse en un aprieto cuando esa forma de organización del poder entre en crisis o comience a sufrir un proceso de transformación. Pero, en segundo lugar, y ello no es menos importante, esta crisis también se debe a la incapacidad por parte de la sociedad contemporánea de crear una memoria dentro de un flujo acelerado y anárquico de los acontecimientos que tanto el mundo como los medios de comunicación ofrecen.

En este contexto el monumento arqueológico va sufrir un doble proceso. Por una parte pierde su sentido, en tanto que queda desligado de la memoria comunitaria y de la visión historicista. Y, por otra parte, recupera su sentido convirtiéndose, al igual que el acontecimiento histórico, en una mera imagen. Ahora bien esa imagen quedará descontextualizada, alienada y carente de sentido. La imagen se le ofrece al espectador, al igual que la noticia. El espectador, en ambos casos, se verá indefenso ante ella. Sólo puede captar su sentido o bien mediante el comentario que se le ofrece, al igual que ocurre con la noticia, o bien saliéndose del sistema de comunicación de masas y volviendo al texto escrito -ya sea en papel o en versión electrónica-, con el fin de poder pensar la imagen. Pensar la imagen es por una parte imaginar su sentido y por otra realizar un acto de comprensión de esa misma imagen en función del contexto en el que se desenvolvió. En todo caso supone una vuelta a la cultura letrada.

Esa vuelta a la cultura letrada sólo será posible si se dan socialmente una serie de condiciones, que van desde el desarrollo de un sistema educativo, a la oferta de una amplia serie de medios de comunicación escritos, tanto en bibliotecas como en el mercado 
editorial. Sin ellos el espectador quedará aislado ante unos medios de comunicación que no controla y será incapaz no sólo de encontrarle un sentido al pasado, sino también al propio presente.

Si se reduce a ese sistema su acceso al monumento arqueológico tendrá que desarrollarse mediante otra vía que será objeto de nuestra segunda tesis.

\section{El monumento arqueológico ha llegado a convertirse en una mercancía}

Las reliquias del cristianismo antiguo y medieval eran objeto de adoración. Los monumentos nacionales, diseminados a través del cuerpo de la patria son un simbolo de la existencia de la misma en el pasado y en el presente. A veces es preciso defenderlos, como es preciso defender las fronteras o el territorio. Esos monumentos pueden, como las reliquias, ser un objeto de culto -aunque eso sí de un culto cívico- y constituyen lo que Pierre Nora ha llamado los lugares de la memoria, gracias a los cuales una nación lleva a cabo una identificación con su pasado, en tanto que esos lugares se identifican con un acontecimiento que posee un gran valor simbólico dentro del relato de la historia nacional. Pensemos, por ejemplo, en Masada, la última fortaleza de los zelotas, que prefirieron morir antes que rendirse a las legiones romanas. Masada, excavada por arqueólogos israelies, se ha convertido en un lugar de culto nacional, en ella realizan su juramento las tropas de élite del ejército de Israel, que al concebirse como una nación sitiada por los pueblos árabes se asimila metafóricamente a la fortaleza asediada.

Si a un monumento se le resta su dimensión como lugar de culto -con sus reliquias o sin ellas- o su papel como catalizador del culto cívico, nos enfrentaremos a dos alternativas. La primera de ellas consistiria en darle valor histórico, es decir, en concebirlo como una obra realizada por los seres humanos del pasado, cuyo uso y cuyo significado es necesario comprender a través de una labor de esfuerzo intelectual, que estará mucho más allá del propio monumento. Si se desecha esa vía, lo que supone abandonar la cultura letrada, de la que es indisociable, únicamente nos quedará un camino, que es el de convertir el documento en mera mercancía.

Actualmente suele hablarse de bienes culturales, cuyo uso y circulación está regulado por las leyes. Las reliquias en la Edad Media también eran un bien, de hecho se intercambiaban, se regalaban, e incluso podían comprarse. Coleccionar reliquias era adquirir un capital, pero un capital simbólico, del que el capital mercantil era sólo una parte. El prestigio de un monasterio o una catedral dependia de las reliquias que poseyese, y para ello se realizaron enormes colecciones. Ese prestigio meramente religioso daba crédito a la institución que lo poseyese, de ese crédito derivaba su poder espiritual, y del poder espiritual derivaba su poder material -conseguido a través de las donaciones.
En el caso del patrimonio nacional los monumentos también forman parte de un capital que podiamos Ilamar ontológico. Quien posee monumentos posee pasado, y quien posee pasado posee una sustancia, que es la garantía de su identidad. Y no sólo ello, sino que esos monumentos, en tanto que están asociados a acontecimientos históricos -por ejemplo batallas (piénsese en Numancia y Sagunto, el Monte Medulio...)- son también depositarios de la gloria, que contribuye a teñir esa identidad de un aura de valor positivo.

Si no visitamos un monumento por razones religiosas o patrióticas, nos quedan dos caminos, o bien acercarnos a él guiados por la curiosidad histórica, o bien visitarlo como turistas. Estando caracterizada la primera de esas vías pasaremos a detenernos en la segunda.

Es sin duda el turismo una de las industrias importantes en la sociedad contemporánea -siempre que nos situemos en el ámbito de los países ricos. El turismo puede realizarse por diferentes razones, y por ello existen diferentes modalidades de él. Vamos a centrarnos en una de ellas: el llamado turismo cultural.

En tanto que el turismo es una industria se desarrolla en el ámbito del mercado y dentro de las leyes del mercado. De acuerdo con ello el turista adquiere un bien a cambio del pago de un precio. En este caso el bien adquirido no posee valor económico directo, sino más bien valor simbólico. El turista normalmente no colecciona antigüedades, sólo las mira, o las adquiere simbólicamente, mediante la compra de recuerdos o de reproducciones de las mismas.

En este proceso tenemos por una parte al turista, que aparece como consumidor, y por otra parte una serie de instituciones, públicas o privadas, que son quienes realizan la "oferta cultural". En el momento presente parece darse un consenso según el cual existe un mercado de bienes culturales, con sus leyes de oferta y demanda. En él, como en el caso de las reliquias medievales, se ofrece un capital simbólico, cuyo consumo no es algo tangible, pero que también se convierte en capital mercantil, ya que el turismo cultural genera beneficios que acaban recayendo en el ramo de la hostelería o las compañías que realizan los viajes.

El peregrino medieval, en busca de reliquias, se movia, en principio, por un motivo religioso. El ciudadano patriota visita los monumentos guiado por un sentido político ¿Qué es lo que mueve al turista y a quién ofrece bienes culturales para el consumo? El turista es impulsado, o bien por la curiosidad, o bien por la necesidad de acumular un curriculum, de ganar prestigio visitando los lugares que se supone que personas de una determinada posición económica y social "deben haber visto". El haber visitado esos lugares sirve como medio de exhibición -ante otras personas- de los bienes que posee el turista y que le permiten viajar, o de su curiosidad por interesarse en lo que 


\section{Investigación \\ Acerca de la crisis del \\ conocimiento histórico y \\ del mercado de los bienes \\ culturales \\ José C. Bermejo Barrera}

uno debe interesarse. El turista puede acceder a un monumento guiado por dos tipos de curiosidad. 0 bien por una curiosidad histórica, que le llevará a tratar de comprenderlo e incluirlo en un red de conocimientos que ya posee de antemano, o que está dispuesto a adquirir, o bien por una curiosidad banal, que le llevará a visitar el monumento para decir que lo ha visitado a lo largo de una conversación intrascendente. El producto cultural, de este modo, acaba en la cháchara. La cháchara, la conversación intrascendente, se desarrolla dentro de unos marcos sociales determinados. Normalmente a pequeña escala, a nivel comunitario, con lo cual tenemos de nuevo al monumento inmerso en un nuevo sistema de comunicación social, el propio del grupo familiar o del grupo de amigos.

Esas pequeñas comunidades en las que se desarrolla la cháchara suponen la existencia de grupos de comunicación que tratan de desarrollar formas de sociabilidad que hagan frente a un tipo de sociedad regulada a todos los niveles por el mercado, en la que el individuo se encuentra aislado frente a las fuerzas económicas, e inerme ante los sistemas de comunicación de masas. Pero la cháchara en esos grupos no supone, en modo alguno, un intento de no compartir la lógica de ese sistema, sino que, en cierto modo, está incentivada por ese propio sistema, en el que se integran los miembros de ese pequeño grupo como consumidores en el mercado, como parte del mercado de trabajo, como espectadores ante los medios de comunicación, y como turistas consumidores de la industria cultural.

En un principio el mercado es un mecanismo autorregulador en el que convergen la oferta y la demanda, de modo tal que las necesidades de los consumidores son las que crean la oferta de una serie de productos que esos consumidores adquieren. Esta es la visión tradicional del mercado, tal y como fue desarrollada por los economistas liberales. Hoy sabemos, sin embargo, que la realidad es un poco más compleja. Hay en efecto una serie de necesidades básicas -alimentación, vivienda-, con unos mínimos que el mercado debe satisfacer de modo tal que la demanda crea la oferta. Pero también es cierto que, en muchos casos, es la oferta la que crea la demanda. Son los nuevos productos los que no sólo atraen la atención de los consumidores, sino que también inducen en ellos la necesidad de adquirirlos. En la economía actual podriamos afirmar que la vieja distinción entre valor de uso y valor de cambio ha perdido ligeramente su sentido.

Un producto se integra en el mercado cuando adquiere un determinado valor de cambio, y el uso que pueda poseer ese producto puede ser, a su vez, de utilidad inmediata, o de naturaleza meramente simbólica. En el caso de los bienes culturales, aparte del valor de cambio que puedan adquirir en el mercado, su valor específico es de naturaleza meramente simbólica. Sin embargo, tanto en este caso como en el de los mercados en general, debemos señalar que es un hecho bien establecido no sólo que a veces la oferta crea la demanda, sino que también muchas veces hay quien controla el mercado: las grandes compañías en la mayor parte de los casos que tienen que ver con los bienes que suelen estudiar los economistas, y las administraciones públicas y algunas instituciones en el caso de los mercados culturales.

Es evidente que las obras de arte y los materiales arqueológicos circulan en un mercado internacional controlado por empresas privadas, galerías de arte y anticuarios. Pero no es ese el mercado que ahora interesa, ya que a él únicamente puede tener acceso un número muy limitado de personas que disponen de grandes recursos económicos. El mercado que ahora nos interesa es el del consumo de bienes culturales por parte del gran público, a través de las exposiciones y visitas a museos y monumentos. En dicho mercado por lo general quien realiza la oferta son las instituciones públicas, o determinadas instituciones, como la iglesia católica o algunos museos privados.

Lo que nos interesa destacar ahora es que quienes se sitúan del lado de la oferta utilizan una determinada lógica, que va mucho más allá de cubrir una supuesta demanda cultural. En la Edad Media los poseedores de reliquias ofertan la gracia, un capital simbólico que administra la iglesia y cuya utilización consiste en adquirir participaciones en la salvación. La administración de la gracia es inseparable de un proyecto político en el que la iglesia controla al cuerpo de los fieles gracias a su papel como distribuidora de ese capital simbólico. Dicho control está muy claro, en tanto que la gracia únicamente puede adquirirse llevando a cabo una determinada conducta de acuerdo con los cánones morales que la propia iglesia establece.

En el caso del Estado-nación ocurre algo similar. La administración de los monumentos forma parte de un proyecto político, en el que la implantación de la enseñanza de la historia nacional puede ser utilizada como un programa para controlar la conducta de los ciudadanos, que ahora ya no se ven encuadrados bajo la figura del buen cristiano, sino bajo la del buen ciudadano y la del buen patriota. La historia nacional y los monumentos anejos a ella llevan consigo determinados modelos de conducta militar, política y cultural, a los que se supone que un buen ciudadano debe ajustarse, ya que su ser es sólo una parte de ese ser nacional y su identidad es inseparable de la identidad de la nación. El Estado administra el capital simbólico constituido por los monumentos mediante la ejecución de determinados ritos, como los de Masada, a los que habíamos hecho referencia, o bien promoviendo su visita como parte de un programa de educación nacional.

En el momento presente la situación ha cambiado del siguiente modo. A partir de la Segunda Guerra Mundial ha venido desarrollándose en el mundo occidental -el caso de la antigua URSS y sus satélites sería diferente- un proceso de desdibujamiento del Estado-nación y de progresiva aparición del Estado-administrati- 
3, 4 y 5. En la concepción comunitarista del pasado y la memoria, el monumento arqueológico asume el papel simbólico de ser un resto glorioso del mundo de nuestros antepasados. Desde la visión historicista el monumento arqueológico es bueno para pensar; no puede ser comprendido de forma inmediata y de un modo directo, sino a través de un trabajo histórico

vo, gestor del bienestar de los ciudadanos. El Estado-administrativo se define ante todo por su capacidad de gestión de una serie de recursos, sanidad, educación, pensiones y bienestar económico en general, mientras que el Estado-nación se definía ante todo como protagonista de su enfrentamiento con otros Estados, a través de la guerra. En el Estado-nación tiene primacia la política exterior -uno de los principios de la historiografía del siglo XIX, tal y como los estableció L. von Ranke-, por el contrario en el Estadoadministrador la política interior posee una clara primacía sobre la política exterior.

En este último tipo de Estado el ciudadano se define como un consumidor de servicios: sanidad, carreteras, educación, que el Estado ofrece. Ese Estado, sin embargo, al contrario de lo que ocurría con el Estado-nación o con la iglesia, parece no aspirar a controlar la conducta de sus ciudadanos. Ese tipo de Estado corresponde a un modelo de sociedad abierta, en la que deberían convivir distintos tipos de opciones morales, y que debe estar regida por la idea de la tolerancia. Sin embargo es precisamente de la naturaleza de ese Estado de donde deriva un problema y es que el Estado pierda parte de su razón de ser, o que su razón de ser, al quedar reducida a la de un mero gestor, pierda gran parte de su dignidad. Por esa razón el Estado-administrativo, que ya no ofrece ningún modelo moral ni religioso a seguir, cree que debe desarrollar una política cultural. El problema viene dado por la propia naturaleza de la cultura que se ofrece, que tiene que ser una cultura apta para un ciudadano que se define como consumidor, y que consecuentemente también tiene que definirse en términos de mercado.

Los bienes culturales pasan así a ser gestionados como cualquier otro tipo de bienes. La aplicación a ellos de la lógica administrativa y de mercado es relativamente sencilla. Lo que, por el contrario, resultará mucho más difícil es definir su naturaleza especifica, o lo que es lo mismo su valor de uso, puesto que en el valor de cambio no se diferencian de cualquier otro tipo de bien. En este sentido podríamos decir que existe el peligro de que esos bienes se conviertan en auténticos simulacros.

Ya habíamos visto cómo los monumentos arqueológicos se habian quedado reducidos a ser meras imágenes. Lo mismo ocurre con el conjunto de los restantes bienes culturales. Si queremos superar el estadio que viene marcado por la naturaleza del bien cultural como mera mercancía carente de valor de uso, será necesario otorgarle un significado. Pero el proceso por el que se le otorga significado a un bien cultural no puede venir dado ni por la lógica del mercado -que sólo sirve para intercambiar- ni por la lógica de la administración, que únicamente sirve para ponerlo aparentemente al alcance de todos los ciudadanos. Un bien cultural o un monumento sólo puede adquirir sentido, o significado, si se lo integra en un discurso, en un universo de significados en los que el pasado posee un determinado valor: o lo que es lo
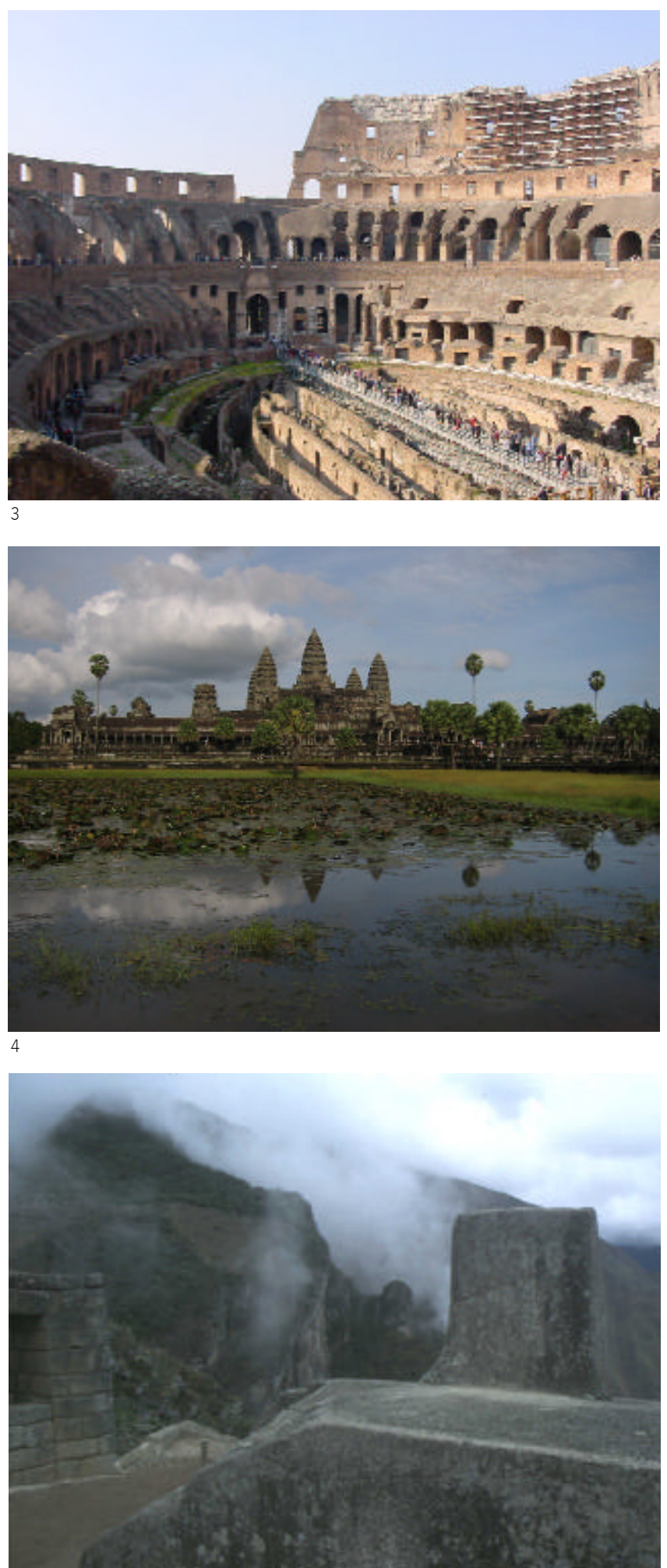


\begin{tabular}{|l|}
\hline Investigación \\
Acerca de la crisis del \\
conocimiento histórico y \\
del mercado de los bienes \\
culturales \\
José C. Bermejo Barrera \\
\hline
\end{tabular}

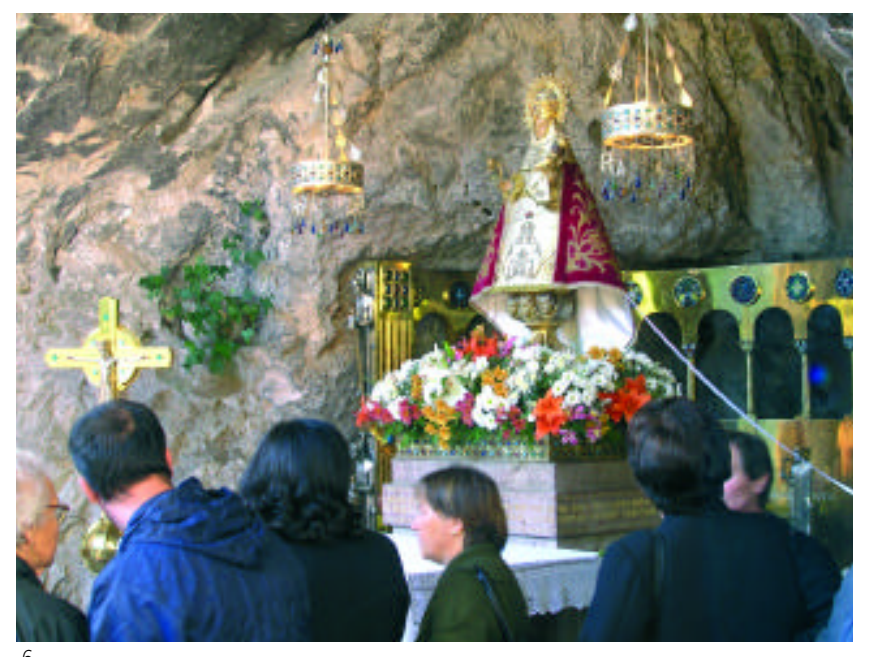

6

mismo sólo puede adquirir sentido si se lo integra en el discurso de la historia.

Pero el discurso de la historia ha entrado en crisis, debido a su identificación con el Estado-nación, con lo cual sería necesario, o bien suprimir la historia, o bien replantearla sobre otras bases.

La pérdida de credibilidad de los relatos históricos no es sólo una profecía que sale de la boca de algunos historiadores, sino un hecho social, consecuencia de las transformaciones que viene sufriendo el Estado. Indicativo de este hecho es, por ejemplo, el peso que la historia del tiempo presente viene alcanzando últimamente. Valorar el tiempo presente en la historia es algo tremendamente positivo, ya que al fin y al cabo, como señaló Benedetto Croce, "toda historia es historia contemporánea". Pero la valoración que se viene llevando a cabo últimamente va en otro sentido, ya que de lo que se trata es de negarle todo valor explicativo al pasado. Para comprender el tiempo presente únicamente debemos remontarnos a la Segunda Guerra Mundial, o ya situándonos en la "larga duración", a la Revolución Francesa. Ni la Edad Media, ni Grecia, ni Roma (por no mencionar la Prehistoria) pueden servir de nada para comprender la política del presente o el funcionamiento de un mundo globalizado. Y no sirven de nada porque la historia pierde su sentido si nos salimos del mundo de los valores de las culturas contemporáneas y nos adentramos en concepciones del mundo tan extrañas como las de los griegos antiguos o de los cazadores paleolíticos. Esta es la idea que nos transmiten muchos historiadores del tiempo presente, cronistas de su propia cultura, cuyo valor viene a verse confirmado por un discurso histórico en la que ella habla como ventrílocua.

Si la situación en la que nos encontramos es ésta será muy dificil que los monumentos arqueológicos adquieran sentido en el
6 y 7. Los monumentos pueden, como las reliquias, ser un objeto de culto y constituyen lo que Pierre Nora ha llamado los lugares de la memoria, gracias a los cuales una nación lleva a cabo una identificación con su pasado

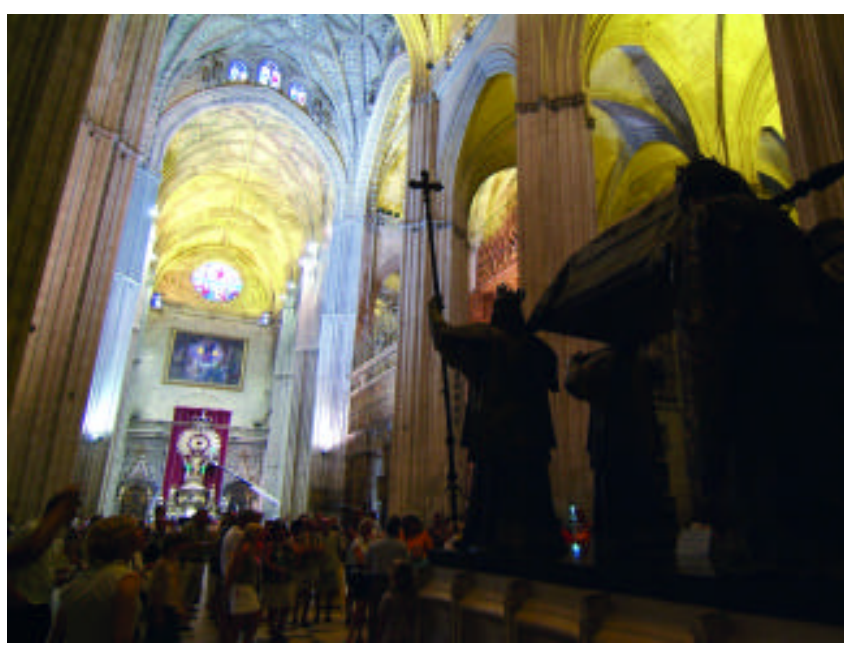

seno de un discurso histórico. Su valor quedará reducido a ser el de meras imágenes, que pueden ser atractivas por su belleza 0 por su exotismo, pero que, en el fondo, no tienen nada que sea verdaderamente interesante que decirnos, quedándose reducidos a meros simulacros que circulan rápidamente siguiendo las leyes del mercado.

Esta situación trae consigo además otra consecuencia, y es que el monumento arqueológico, o el bien cultural, pasan a convertirse en un mero fenómeno, en algo que es meramente apariencia, pero que no esconde ningún significado tras de sí. Lo que nos lleva a desarrollar la siguiente tesis.

\section{Para cumplir bien las leyes del mercado cultural el monumento arqueológico debe ser absolutamente explícito}

Si no estamos dispuestos a realizar ningún esfuerzo intelectual que nos permita imaginar y comprender una sociedad del pasado, entonces el monumento arqueológico ideal es aquel que se nos ofrece como un producto acabado. Un monumento arqueológico es un fragmento, un documento histórico es un fragmento que nos transmite un destello de la vida de los seres humanos del pasado. La conservación de documentos y monumentos es arbitraria. Sobreviven según las circunstancias meteorológicas y si las condiciones físico-químicas lo permiten, y si muchos llegan a nosotros es debido a la escasa voracidad de los ratones y de las personas que decidieron no utilizarlos.

Comprender el pasado supone ante todo un esfuerzo de reconstrucción, esfuerzo que ha de llevarnos más allá del documento y del monumento, y que nunca podrá permitirnos captar la totalidad de ese pasado, sino únicamente algunas migajas del mismo. Comprender el pasado es indisociable de una reflexión sobre la 
sociedad y el pensamiento de los seres humanos del pasado. Pero esas reflexiones no están necesariamente favorecidas por la transformación de monumentos y documentos en bienes culturales.

La lógica que se demanda es una lógica muy distinta, que creo que puede ser comprendida a través de un paralelismo entre el discurso de los bienes culturales y el discurso pornográfico, aunque ello pudiera parecer chocante, puesto que en ambos se da el mismo proceso de empobrecimiento y de reducción a estereotipos.

Conviene abordar este tema partiendo de una concepción que se aleje mucho del puritanismo que la existencia de la pornografía puede suscitar y de supuestas consideraciones maximalistas en contra del mercado. En primer lugar deberemos tener en cuenta que la pornografía es una industria que mueve miles de millones de pesetas, en sus diferentes manifestaciones, en las sociedades industrializadas y de tradición liberal en las que no hay razones religiosas o morales que impidan su circulación. Puede criticarse su existencia diciendo que supone una comercialización del sexo, pero este argumento no es más que una moralina. En la sociedad actual está todo más o menos comercializado, lo bueno y lo malo, y por lo tanto este hecho no tiene por qué estar relacionado con el valor de uso de un producto, y en ese sentido la pornografía es un producto más.

La pornografia puede servir para cubrir las demandas sexuales de sus consumidores, pero no es este el tema que ahora nos interesa sino su lógica interna, con el fin de ponerla en relación con la lógica del monumento arqueológico absolutamente explícito.

A lo largo de su historia la humanidad ha venido creando historias de diferente tipos -mitos, cuentos, novelas-, en los que las relaciones amorosas desempeñaron un papel fundamental. Pero en la mayor parte de esos relatos, como por ejemplo en la novela erótica griega, la trama narrativa está compuesta por una serie de intrincados episodios que acaban en la unión de sus protagonistas, unión que es el fin del relato, pero que nunca es descrita. En esos tipos de relatos las relaciones sexuales se entienden como relaciones sociales, y por lo tanto se hallan integradas en un entramado social complejo.

En el relato pornográfico, y sobre todo en las películas de este tipo, la trama narrativa tiende a desaparecer, o desaparece por completo, las relaciones sexuales saltan todos los límites sociales, y lo fundamental es la descripción absolutamente explícita de los actos sexuales, en la que no debe quedar nada oculto. Esas imágenes y esos relatos circulan para cubrir determinadas demandas sexuales de sus consumidores, pero además de ello son también reflejo de un hecho sociológico que afecta a las sociedades contemporáneas: la transformación de la imaginación.
En los relatos amorosos la imaginación, que va a la par del análisis de las relaciones sociales, funciona partiendo de una lógica según la cual existen dos mundos, el de la apariencia y el de la realidad que se oculta tras ella. Estos dos mundos se hallan íntimamente unidos, de forma que es imposible separar apariencia de esencia, y de modo tal que la esencia, siempre oculta, sólo se nos puede revelar a través de la apariencia. En el discurso pornográfico no hay nada que ocultar, únicamente existe una realidad: la de las relaciones sexuales directas, a las que se podrían reducir todas las demás relaciones sociales. Y esas relaciones se muestran en toda su plenitud. Dicen todo lo que tienen que decir, que en último término no es nada, ya que la realidad última es una relación física que va más allá del lenguaje, y a la que debemos acceder.

En el discurso de los monumentos arqueológicos considerados como bienes culturales la situación ideal vendría dada por las coordenadas siguientes. En primer lugar el bien arqueológico debe ser accesible a todo el mundo y debe estar expuesto. Todos los consumidores en pie de igualdad tienen que tener acceso a él y poder disfrutarlo de una manera inmediata. El monumento arqueológico debe decir a primera vista todo lo que tiene que decir. Su apariencia debe mostrar su esencia.

Por esta razón debemos superar su carácter de fragmento y ofrecerlo, a ser posible, como una reconstrucción, tal y como se ofrecen en Francia y en Inglaterra, o en los Países Nórdicos, determinados monumentos arqueológicos (el campamento vikingo de Fyrkat, el poblado de Biskupin, el parque arqueológico de Pfahlbauland, el hillfort de Castell Hengys, etc.).

En estos casos el visitante no tiene que realizar ningún esfuerzo para percibir la "realidad histórica". Está viendo las cosas tal y como eran -se supone-, y es su contacto con esas imágenes lo que le garantiza la percepción de esa "realidad". Ahora bien, si el visitante desconoce las relaciones sociales que generaron esos monumentos, el mundo de las creencias que pueden hacerlos comprensibles y el medio físico en el que estaban situados, estará ocurriendo lo mismo que en el discurso pornográfico. En ambos casos la imagen se muestra a sí misma en toda su plenitud para decirnos que lo único que hay es eso: una mera imagen, que no hay nada detrás, y que el disfrute de esa imagen es el propósito que se persigue. Se trata de ofrecerle un producto agradable al consumidor para que se autosatisfaga con contemplación.

Naturalmente se me podrá decir que en arqueología nadie puede percibir las relaciones sociales del pasado, y mucho menos el mundo de las creencias que produjeron esos monumentos. Ello es cierto, pero también lo es que si no intentamos, mediante la comparación etnográfica o el análisis de las técnicas, llegar a esas relaciones y esas formas de ver el mundo, entonces la arqueología quedaría reducida a un mero coleccionismo de antigüedades, que puede alcanzar un sentido cuando esas anti- 


\section{Investigación \\ Acerca de la crisis del conocimiento histórico y del mercado de los bienes culturales \\ José C. Bermejo Barrera}

güedades sean reutilizadas (piénsese en la reutilización del polvo conseguido moliendo momias egipcias como instrumento mágico a partir de fines de la antigüedad) con fines religiosos, económicos (piénsese en la reutilización de piedras de los monumentos como material de construcción) o de mero prestigio.

Si la arqueología no quiere verse reducida a una exótica forma de coleccionismo, ni quiere entrar en los caminos del esoterismo, únicamente le quedarán dos caminos. 0 bien en convertirse en una historia de la tecnología, en la que se analice la producción de distintos objetos y bienes en el pasado, o bien integrarse en el discurso de la historia -del que también forma parte la historia de la tecnología. Pero integrarse en ese discurso supone trascender a los objetos arqueológicos e integrarlos en sistemas productivos, tramas de relaciones sociales y mundos simbólicos del pasado, y eso es imposible sin un trabajo intelectual.

Las reconstrucciones arqueológicas pueden ser útiles para comprender el funcionamiento de las tecnologías del pasado y como ficciones hermenéuticas que puedan ayudar a desarrollar nuestros procesos de comprensión. Pero también pueden ser enormemente peligrosas cuando se comercializan, se integran en circuitos turísticos y se ofrecen al consumo de los ciudadanos como productos acabados que pueden otorgarles una satisfacción inmediata.

La exhibición de esos productos es ofrecida en la actualidad al gran público por parte de empresas privadas, que construyen "parques temáticos" en los que se ofrecen simulacros de monumentos del pasado, y por parte de las administraciones públicas, que pretenden llevar a cabo de este modo una política "cultural". Dicha politica forma parte de la política general del Estado-administrador, cuya misión es poner al alcance de la mayor parte de los ciudadanos lo que se supone que son los bienes comunes. Pero un monumento no es un alimento, ni una medicina, ni nada que pueda contribuir al mantenimiento de la salud o el bienestar de la población. Un monumento no tiene sentido si no se le otorga un significado. En este sentido el Estado-administrador se encuentra ante varias alternativas para otorgárselo. 0 bien recurrir a la lógica del Estado-nación y ofrecer el monumento como muestra de la gloria de nuestros antepasados nacionales, o bien recurrir al localismo y ofrecérselo a los curiosos como algo que es característico de nuestro pueblo o nuestra ciudad, pasando así de la historia nacional a la erudición local, o bien fomentar la educación de la población, no sólo a través de la enseñanza, sino también a través de los medios de comunicación de masas y mediante la difusión de la cultura escrita, con el fin de que los ciudadanos, que no los consumidores, integren en su universo mental y simbólico los monumentos del pasado.

Para ello los ciudadanos tendrán que llegar a ser conscientes de que el pasado no es bien de consumo incluible en un recorrido turístico sin más, de que el pasado no nos es accesible sin más, sino que su conocimiento es indisociable de una labor de reconstrucción del mismo, y por ello deberemos desarrollar nuestra última tesis.

\section{El monumento arqueológico debe ser considerado como un instrumento para el conocimiento del pasado, y consecuentemente, de nosotros mismos}

Esta última tesis se diferencia de las tres anteriores en su carácter normativo. En las tres primeras, en efecto, se describía lo que el monumento había llegado a ser. Ahora, por el contrario, se trata de indicar lo que debería ser. En este sentido puede resultar paradójico que se proponga utilizar el monumento como instrumento, puesto que uno de los principios más evidentes en arqueologia e historia del arte es que un monumento posee valor por si mismo. Es su materialidad lo que hay que conservar, debemos defender su integridad y procurar su conservación. Por ello toda reconstrucción puede ser peligrosa si no se respeta la lógica del original, para lo que se supone que existen técnicas.

A lo largo de milenios la humanidad ha venido destruyendo los monumentos del pasado, y si los ha conservado ha sido porque ha sabido hallarles alguna utilidad, con lo cual los monumentos del pasado siguieron siendo monumentos del presente (piénsese en las murallas, catedrales...). Evidentemente no es ésta la utilización de los monumentos como instrumentos que proponemos, sino su uso como medios de conocimiento.

En ese uso la integridad del monumento no es el valor fundamental, ni tampoco su materialidad, sino su valor cognoscitivo. El monumento posee valor porque tiene un significado, un significado que puede tener que ver con las técnicas de construcción, con las relaciones sociales que han podido tener lugar en él o alrededor de él, y con el conjunto de valores simbólicos que gravitaron a su alrededor.

El pasar de la materialidad del monumento al mundo de significado, o lo que es lo mismo, al mundo del lenguaje, es labor de la arqueología. Y ello es así aunque no conozcamos el lenguaje de las personas que construyeron o vivieron en y en torno al monumento. Si poseemos conocimientos de su lenguaje, a través de los documentos, la arqueología se integra en la historia y si éste no fuera el caso estariamos normalmente en el ámbito de la prehistoria. En este segundo caso el desconocimiento del lenguaje del pasado limita sustancialmente nuestras posibilidades de reconstruir los usos del monumento, pero no las invalida totalmente, ya que en las culturas humanas existe un componente no lingüístico: gestos, técnicas y algunas formas de pensamiento no predicativo, lo que unido a la comparación etnográfica puede proporcionarnos algún conocimiento acerca del pasado. 
8. En el mercado, el bien cultural debe ser accesible a todo el mundo y debe estar expuesto. Se ha de superar su carácter de fragmento para que el visitante no tenga que realizar ningún esfuerzo de percepción histórica

9. El monumento posee valor porque tiene un significado, un significado que puede tener que ver con las técnicas de construcción, con las relaciones sociales que puedan haber tenido lugar en él o alrededor de él, y con el conjunto de valores simbólicos que gravitaron a su alrededor

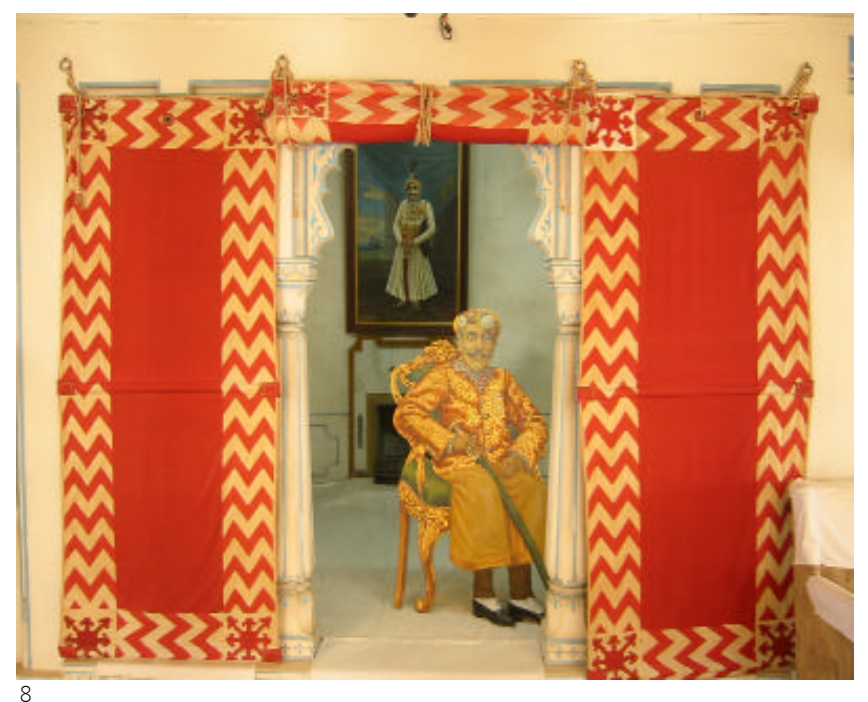

Pero tanto en el caso de que dispongamos del lenguaje como en el que no -y ello será mucho más evidente en el segundo de ellos- deberemos ser conscientes de que el conocimiento histórico, del que el conocimiento arqueológico no es más que una parte, es un conocimiento fragmentario. En él será imposible llegar a alcanzar un conocimiento pleno del pasado -del mismo modo que es imposible alcanzar un conocimiento pleno del presente, al que sí podemos observar directamente. La historia total es una mera ficción, su formulación es expresiva, más que del pasado mismo, de la propia visión que de él tienen los historiadores. Los historiadores manejan unos métodos para analizar los documentos o los monumentos, si son arqueólogos, y del uso de esos métodos depende su respetabilidad académica. Por esa razón creen que es necesario afirmar su omnipotencia y sostener que, gracias a ellos pueden conocerlo todo y conocerlo bien. Si algo quedase sin conocer el método parecería imperfecto, y consecuentemente podriamos poner en duda la competencia del historiador. Por ello el conocimiento histórico se define a sí mismo como cerrado. En nuestro caso ese mundo perfecto del pasado agotado, exhaustivamente conocido a través del conocimiento histórico, vendría a ser el equivalente del monumento íntegramente reconstruido. No queda en él nada que no podamos ver, que no podamos conocer. Sólo hay una diferencia: el pasado lo conocemos "tal y como fue", y el monumento reconstruido es "como si fuese" el pasado.

Historiadores y arqueólogos comparten un supuesto metafísico, que nunca llegan a formular, puesto que en ambos casos nos encontramos con gente amiga de lo empírico y poco dada a la especulación. Ese principio puede llamarse el principio de la armonía preestablecida entre el historiador y sus documentos. De acuerdo con él el número de documentos de los que disponemos (aún sabiendo que siempre es limitado y su transmisión azarosa) es siempre suficiente para otorgarnos un conocimiento significativo del pasado. En arqueologia las culturas se definen por sus fósiles guía (megalítica, del bronce...). Ello

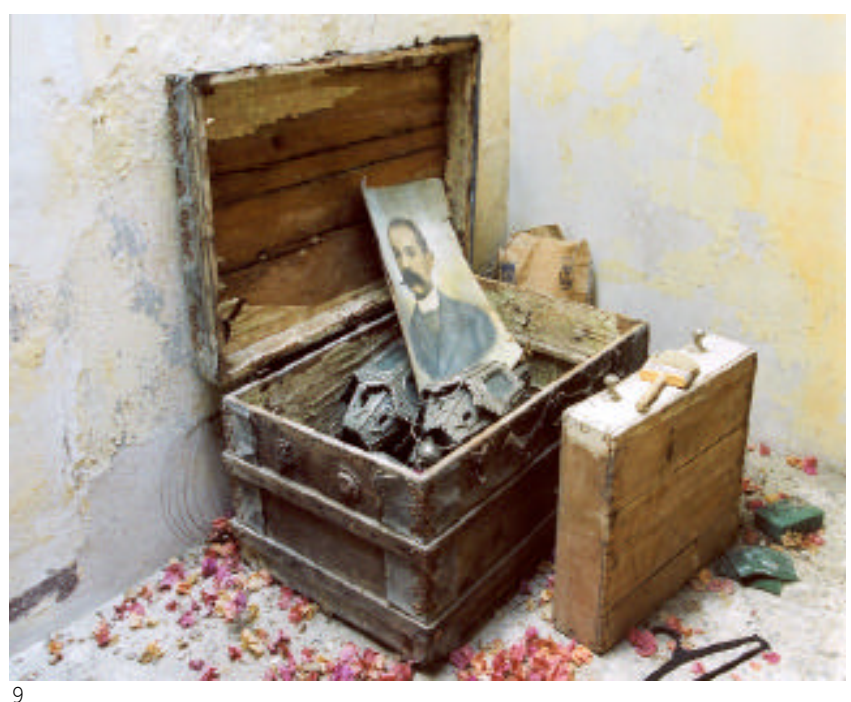

es una manifestación de ese principio. El fósil guia puede definir a una cultura porque es lo que le da significado en el discurso del arqueólogo, discurso que nada tiene que ver con el de la cultura que estudia. Cuando no se conoce el lenguaje de los miembros de una cultura del pasado estamos ante una cultura sin voz. Y lo mismo sucede en parte cuando disponemos de documentos escritos, ya que esos documentos adquieren sentido únicamente dentro del discurso del historiador. En ambos casos el discurso del historiador es un discurso imperialista. El historiador habla acerca del pasado, pero también acerca de sí mismo. Si reconociese la insuficiencia de sus fuentes, tendria que admitir el carácter relativo de su discurso, lo cual no es fácil de hacer en una época como la nuestra de certezas absolutas.

Por ello el historiador y el arqueólogo elaboran un discurso que clausura el pasado, que pretende no dejar resquicios para que puedan desarrollarse otra versión alternativa de él, lo que es coherente si tenemos en cuenta el papel que la historia ha desempeñado como discurso legitimador del Estado-nación o del Estado-administrador, que se rige por un saber administrativo basado en el conocimiento de diferentes "ciencias" (politicas, económicas, sociales...).

Frente a ese discurso creemos que se debe reivindicar el carácter fragmentario del conocimiento histórico y su naturaleza de reconstrucción racional del pasado -como una de sus reconstrucciones posibles-, reconstrucciones que no sólo dependen de los conocimientos que nos ofrecen las fuentes escritas y los monumentos, sino también de nuestras visiones aprioristicas acerca del pasado que derivan de nuestras concepciones antropológicas y sociológicas, cuando no también de nuestros prejuicios y de nuestras ideas morales. Frente a todas ellas, en cuya valoración no vamos a entrar aquí, el monumento arqueológico nos ofrece la posibilidad de servirnos como acicate para desarrollar nuestro trabajo de reconstrucción 


\section{Investigación}

Acerca de la crisis del

conocimiento histórico y

del mercado de los bienes

culturales

\section{José C. Bermejo Barrera}

racional del pasado y para crear los relatos sobre el mismo que aspiren a lograr el consenso de nuestros conciudadanos.

El monumento arqueológico está aquí. En principio es mudo, si no va acompañado de inscripciones, pero con su presencia, que no afirma ni niega nada, nos abre un camino hacia el mundo de la intencionalidad de los seres humanos del pasado. El monumento fue construido por alguien y para algo. Quien lo haya construido ya ha desaparecido, pero el monumento sigue ahí, frente a nosotros, invitándonos a comprender su uso o su valor simbólico. Un diálogo con el pasado es imposible -el historiador no es un invocador de espíritus-, pero los monumentos nos hacen ver que a través de su materialidad yace oculto un mundo de usos y valores, que evidentemente ya no es el nuestro, pero que podría llevarnos a reflexionar sobre el valor relativo de nuestra cultura y sobre el sentido del tiempo. Eso sí, siempre que no lo reduzcamos a una imagen explícita que se ofrece como mercancía para el consumo como bien cultural.

\section{Los panes y los peces: una contribución a la economía política del patrimonio cultural ${ }^{1}$}

Todos aquellos que hemos tenido una educación religiosa sabemos que uno de los milagros con los que Jesús acreditó su naturaleza divina fue la multiplicación de los panes y los peces. Partiendo de dos únicas cestas en las que se contenían estos alimentos, consiguió dar de comer a una inmensa multitud. Si hemos escogido este milagro como título de nuestro trabajo es porque creemos que aquellos que sostienen que la arqueología y la historia del arte justifican su existencia como disciplinas gracias a su rentabilidad económica no sólo cometen un involuntario error, sino que también manipulan la realidad con el fin de justificar unas situaciones de privilegio de las que disfrutan algunos arqueólogos e historiadores del arte que acaparan una buena parte del gasto que los diferentes organismos públicos dedican a un difuso campo que se conoce bajo el nombre de "cultura" (campo que estos ideólogos gustan de definir con una jerga pseudoeconómica como "mercado de la cultura", "servicios culturales" o "industria cultural").

A continuación nos limitaremos a plasmar unas sencillas consideraciones que deberían ser objeto de una serie de estudios cuantitativos complementarios que permitan medir la supuesta rentabilidad de una serie de inversiones públicas (a veces importantes), y que resitúen en el terreno de la realidad las palabras y las estrategias retóricas de la "industria cultural", cada vez más frecuentemente escuchadas en boca de políticos, técnicos del patrimonio, historiadores del arte y arqueólogos. Nuestra tesis de partida será la siguiente:

$>$ Tesis 1: Al contrario que en el mundo de la producción, en el que la productividad de una inversión se incrementa con el número de productos vendidos, en el campo de la supuesta industria cultural
Nota
${ }^{1}$ Aquí comienza el segundo de los textos que se recogen en este artículo, como se indica en el resumen

y del patrimonio la productividad es inversamente proporcional al número de las supuestas mercancías existentes.

Para demostrar nuestra tesis únicamente utilizaremos nociones económicas elementales, con el fin de poner de manifiesto la existencia de un discurso ideológico, de un discurso falso, que se incluye en el marco de una estrategia política.

En cualquier proceso económico que tenga lugar en una economía de mercado, se calcula la productividad de un determinado producto $(\mathrm{x})$ restando del precio al que se vende los costes de su producción:

$\operatorname{Pr}(\mathrm{x})=\operatorname{Pv}(\mathrm{x})-\operatorname{Pc}(\mathrm{x})$

0 , si lo hace porcentualmente, dividiendo la primera cantidad por la segunda.

En la producción de una mercancía intervienen dos tipos de capital: el capital fijo y el capital circulante. El primero es el que permite poner en marcha todo un proceso productivo y mantenerlo en el tiempo; el segundo es el que interviene porcentualmente en la producción de una mercancía singular.

Si definimos un producto $(\mathrm{x})$ que tiene unos determinados costes de producción a lo largo de toda la vida productiva en la que se fabrica, y simplificamos a efectos expositivos la diferencia entre capital fijo y capital circulante, podremos afirmar sin ningún género de dudas que la productividad de toda inversión del capital es directamente proporcional al número de mercancias $(x)$ vendidas:

$\operatorname{Prt}(\mathrm{x})=\mathrm{N}(\mathrm{x}) \mathrm{x} \operatorname{Pr}(\mathrm{x})$

En el caso de la "industria cultural", creemos que la situación es la inversa. Mayores inversiones no significan mayor rentabilidad, ya que se produce un proceso muy rápido de saturación del mercado que desaconseja incrementar la inversión. Esto traería como consecuencia una paradoja en cualquier otro campo de la economía, que se podría formular de la forma siguiente:

> Tesis 2: El valor de un "bien cultural" es directamente proporcional a su escasez. Consecuentemente, pensar que se pueden producir "bienes culturales" de acuerdo con los mecanismos normales de funcionamiento del mercado no tiene sentido técnicamente.

Podríamos ilustrar esta tesis con cualquier ejemplo. El valor de la catedral de Santiago de Compostela deriva de que es única e irrepetible, y desde el punto de vista religioso, de que en ella estaría enterrado (o al menos eso se supone) un apóstol único. Lo que la hace extraordinaria es su singularidad. Pensar en un proceso productivo de mercancías similares carece de sentido.

Siguiendo con nuestro análisis, elaboraremos un modelo, centrándonos en el campo de la arqueología, en el que sí es posible 
descubrir nuevos yacimientos, que no es el caso de las catedrales. No obstante, en este mundo tampoco sería aplicable la lógica de la producción mercantil.

Queremos demostrar que la productividad de la arqueología es inversamente proporcional al número de yacimientos existentes: $\operatorname{Pr}(\mathrm{A})=\operatorname{Pr}(\mathrm{y}) / \mathrm{N}(\mathrm{ys})$

La productividad de la arqueología, de acuerdo con esta tesis, se calcularía dividiendo la suma de los precios de los "productos arqueológicos vendidos", restándole el precio de sus costes, por el número total de yacimientos existentes como oferta:

$\operatorname{Pr}(A)=\operatorname{Pv}(A)-\operatorname{Pc}(A) / N(y s)$

Se da además el caso de que en el mercado de la arqueología los precios de las ventas se quedan en manos de empresas privadas, mientras que los precios de coste se extraen del dinero público, con lo cual el cálculo de la rentabilidad se hace mucho más complicado.

Los beneficios económicos básicos que genera un yacimiento arqueológico se centran en el sector turístico. Otros beneficios secundarios, como los derivados de la publicación de libros, formarian parte de la industria editorial, cuyo análisis requeriria un estudio aparte, ya que los libros se compran normalmente en un mercado libre, y sí son mercancías.

Desarrollemos nuestro modelo. Una vez excavado un yacimiento, genera una serie de recursos turísticos. Estos recursos podrían formalizarse de la siguiente manera: la productividad de un yacimiento es igual a la suma de los gastos de desplazamiento de todos sus visitantes en un tiempo (t) y los gastos de manutención en ese mismo tiempo. Como el tiempo de desplazamiento es directamente proporcional al espacio o a la distancia, tendríamos que formularlo así:

$\operatorname{Pr}(\mathrm{y}$ en $\mathrm{t})=\mathrm{Gd} \times \mathrm{e} \times \mathrm{t}+\mathrm{Gma} \mathrm{xt}$

Un turista realiza un viaje. Si sólo visita un yacimiento, toda su inversión se va a centrar en él. Si visita varios, habría que dividirla entre ellos. 0 sea:

$\operatorname{Pr}(\mathrm{y}$ en $\mathrm{t})=\mathrm{Gd} \times \mathrm{e} \times \mathrm{t}+\mathrm{Gma} \times \mathrm{t} / \mathrm{N}(\mathrm{y})$

Como el turista invierte su capital en cada yacimiento, la ecuación se convertiría en:

$\operatorname{Pr}(y$ en $t)=(G d x e x t / N)+(G \operatorname{ma} x t / N) / N$

lo que aritméticamente da:

$\operatorname{Pr}(y$ en $t)=G d x e x t+G m a x t / N^{2}$

Económicamente, por lo tanto, la inversión en arqueología es casi irrentable. La demanda no puede crecer a un ritmo proporcional a la oferta, ya que el "producto arqueológico" en un mercado turístico se agota rápidamente. Un turista quiere ver un megalito, un castro o una ciudad romana, no docenas de ellos, a menos que tenga un interés profesional y por lo tanto no sea un mero turista. Si el crecimiento de la demanda es poco elástico, no se puede basar un modelo de desarrollo local o regional en el crecimiento de la oferta, ni puede sostenerse que la investigación arqueológica pueda ser un motor del desarrollo económico a nivel global. Esto sólo sería cierto a un pequeño nivel y en casos más o menos excepcionales, puesto que, como ya hemos visto, el valor del un "bien cultural" es directamente proporcional a su escasez.

Cualquier estudio mínimamente riguroso de este tema exigiría la medición del gasto en turismo arqueológico en correlación con el gasto global en turismo. Aunque ello no esté bien cuantificado, creo que es fácil comprender que el turismo de masas no se mueve por parámetros relacionados con el patrimonio cultural, sino por otros motivos mucho más variados. Pero es que además el análisis económico del patrimonio cultural exige introducir una serie de parámetros nuevos, de tipo no sólo económico, sino también político.

En el "mercado" de la arqueología se da la paradoja de que los costes son públicos y los beneficios privados. Los yacimientos arqueológicos son básicamente propiedad del Estado. No se pueden comprar ni vender, están protegidos legalmente, aún en el caso de que el Estado comparta la propiedad de los mismos con otras instituciones o con personas físicas. Los beneficios que se derivan de un yacimiento cuya excavación se hace con dinero público y cuyo mantenimiento corresponde a la propia administración van directamente a la industria turística. Sólo una pequeña parte de esa inversión se recupera cobrando las visitas, por ejemplo.

Tendriamos así que la productividad de la arqueología sería igual a los beneficios turísticos menos los costes arqueológicos (de excavación y mantenimiento):

$\operatorname{Pr}(\mathrm{A})=\mathrm{B}(\mathrm{Tu})-\mathrm{C}(\mathrm{Ar})$

La Administración obtiene del turismo una serie de ingresos por impuestos, que habría que restar a los propios beneficios del turismo:

$\operatorname{Pr}(A)=[B(T u)-I(T u)]-C(A r)$

Los impuestos generados por el turismo, sumados a los impuestos que genera la propia actividad arqueológica (IRPF + IVA + IBI) podrian restarse del coste arqueológico, con lo que tendríamos: $\operatorname{Pr}(A)=B(T u)-C(A r)-[I(T u)+I(A r)]$

Lo que se cobra en impuestos revierte a la Administración, que es la que sufraga el coste arqueológico. Con lo cual lo que para el mercado es una pérdida, para el Estado es un beneficio.

Naturalmente habria que calcular si lo que invierte el Estado en la investigación y la conservación del patrimonio es mayor o menor que 


\section{Investigación \\ Acerca de la crisis del \\ conocimiento histórico y \\ del mercado de los bienes \\ culturales \\ José C. Bermejo Barrera}

el monto de los impuestos que recauda a través del turismo y del trabajo de las personas que desarrollan su actividad en este campo, pudiendo añadirse el incremento global de la producción de mercancias que genera el consumo turístico y su retorno a las arcas estatales mediante el sistema fiscal. Mientras no tengamos estos datos no es posible ninguna conclusión definitiva. Pero aunque el balance fuese positivo se plantearía el siguiente problema moral y político.

Sea (E) un Estado que genera unos ingresos fiscales que se detraen de la riqueza de sus ciudadanos. Una parte de esa riqueza forma la inversión pública en bienes y servicios de la que se benefician los propios ciudadanos, lo que justifica el cobro de los impuestos. En el caso de la "industria cultural" se da la paradoja de que los únicos beneficiarios son las empresas turísticas privadas. De modo que la población de (E), a la que vamos a llamar Pueblo, invierte como capitalista en un proceso productivo en el cual se produce una mercancía -el turismo- que gestiona una empresa privada de la cual ese mismo Pueblo se convierte en cliente. El turista "consume" un bien arqueológico, del que es propietario como parte de una comunidad nacional. Para consumirlo necesita llevar a cabo una serie de gastos (Gd x e x t $+G m a \times t)$, gastos que sólo benefician a empresas privadas.

Naturalmente que el turista es libre, pero ello no obsta para que se dé la paradoja de que en el mercado de la arqueología quien invierte el C (A) en la "producción" de "mercancías arqueológicas" es a la vez el consumidor de las mismas. Con lo cual su inversión no sólo no le produce beneficios, sino que incrementa sus gastos. El turista cultural es el único capitalista del mercado que no sólo no se beneficia de su inversión, sino que además tiene que realizar gastos para "consumir" una mercancía que ya es suya.

Los beneficiarios de la inversión pública en "bienes culturales" son los empresarios de la industria turística, tanto en el sector de los viajes y el transporte como en el alojamiento y la manutención, y aquel grupo de profesionales que pueden ejercer su labor en empresas privadas o en el propio sector público que se dedican a la excavación y conservación arqueológica, al mantenimiento, cuidado y restauración de las obras de arte y a todos los servicios administrativos que estas actividades implican.

Tenemos, pues, una primera condición para que se desarrolle una ideología del "mercado del patrimonio", entendiendo como ideología una representación falsa de la realidad, que justifica el disfrute de privilegios económicos y sociales. Existen grupos de empresarios que se benefician de ese mercado sin hacer ninguna inversión en la "producción" de las mercancías que venden. Y en segundo lugar, existen otros grupos de empresarios, funcionarios e incluso intelectuales que justifican la existencia de ese "mercado", que se benefician como empresarios propiamente dichos, como trabajadores y como acaparadores de privilegios sociales y politi- cos, del dinero que el Estado, y no ellos mismos, invierte en ese proceso que ellos controlan e incluso monopolizan. Este monopolio se deriva de sus conexiones con las administraciones públicas y con los partidos que en cada momento gobiernan.

¿Por qué apelan al mercado y no piensan el patrimonio con otros parámetros? En primer lugar, porque identifican mercado y sociedad y porque necesitan una estrategia retórica que justifique su enriquecimiento (mayor o menor) y sus privilegios simbólicos y políticos con apelaciones al interés y el enriquecimiento general.

La argumentación subyacente sería la siguiente:

a: Ios "bienes culturales" producen riqueza

b: la riqueza sólo se crea en el mercado

c: luego los "bienes culturales" se producen en el mercado.

a-1: con los "bienes culturales" se enriquece la colectividad (el Pueblo)

b-1: yo formo parte de la colectividad que se enriquece con los "bienes culturales"

c-1: luego yo también debo enriquecerme.

Lo que, en muchos casos, es claramente verdad. Como es necesario justificar esos intereses económicos y esos privilegios, se elabora una teoria del mercado y la rentabilidad que:

1. es falsa porque viola una ley fundamental de la producción económica. Si la rentabilidad es inversamente proporcional al número de mercancías producidas, es absurdo incrementar la producción de mercancías.

2. es también falsa ya que, en ese supuesto mercado, las inversiones son básicamente públicas, mientras que los beneficios son privados.

Además de todo lo anterior, que es analizable en el terreno de las meras relaciones económicas, se olvida un hecho capital: un "bien cultural" sólo es un bien secundariamente. Los cuadros, las catedrales o los yacimientos arqueológicos pueden tener un valor económico, pero ese valor es secundario.

Una obra de arte "vale" si tiene un valor estético. Una catedral, además de un valor estético, puede tener un valor religioso. Los monumentos arqueológicos tienen un valor cultural e histórico. $Y$ todos los monumentos y objetos que forman el patrimonio de una nación tienen un valor simbólico y político.

El valor económico es cuantificable. Los otros valores, no. Quinientos euros es más que cien euros, y todas las mercancías se igualan en el mercado porque son intercambiables por dinero.

Que los "bienes culturales" valgan dinero no quiere decir nada, porque los valores estéticos, religiosos o históricos no son cuan- 
10. Una obra de arte "vale" si tiene un valor estético. Una catedral, además de un valor estético, puede tener un valor religioso. Los monumentos arqueológicos tienen un valor cultural e histórico. Y todos los monumentos y objetos que forman el patrimonio de una nación tienen un valor simbólico y político. El valor económico es cuantificable. Los otros valores no
Imágenes: Martín J. Fernández (1. Templo de Dendera, Egipto), Isabel Luque (2. Ashilá, Marruecos; 4. Angkor, Camboya; 5. Machu Picchu - Intihuatana, Perú; 8. Palacio de Udaipur, India), Marta García de Casasola (3. Coliseo, Roma), José Manuel Santos (6. Covadonga, Asturias; 7. Monumento a Colón en la Catedral, Sevilla), Beatriz Carmona (9. Baúl), Beatriz Sanjuán (10. Londres).

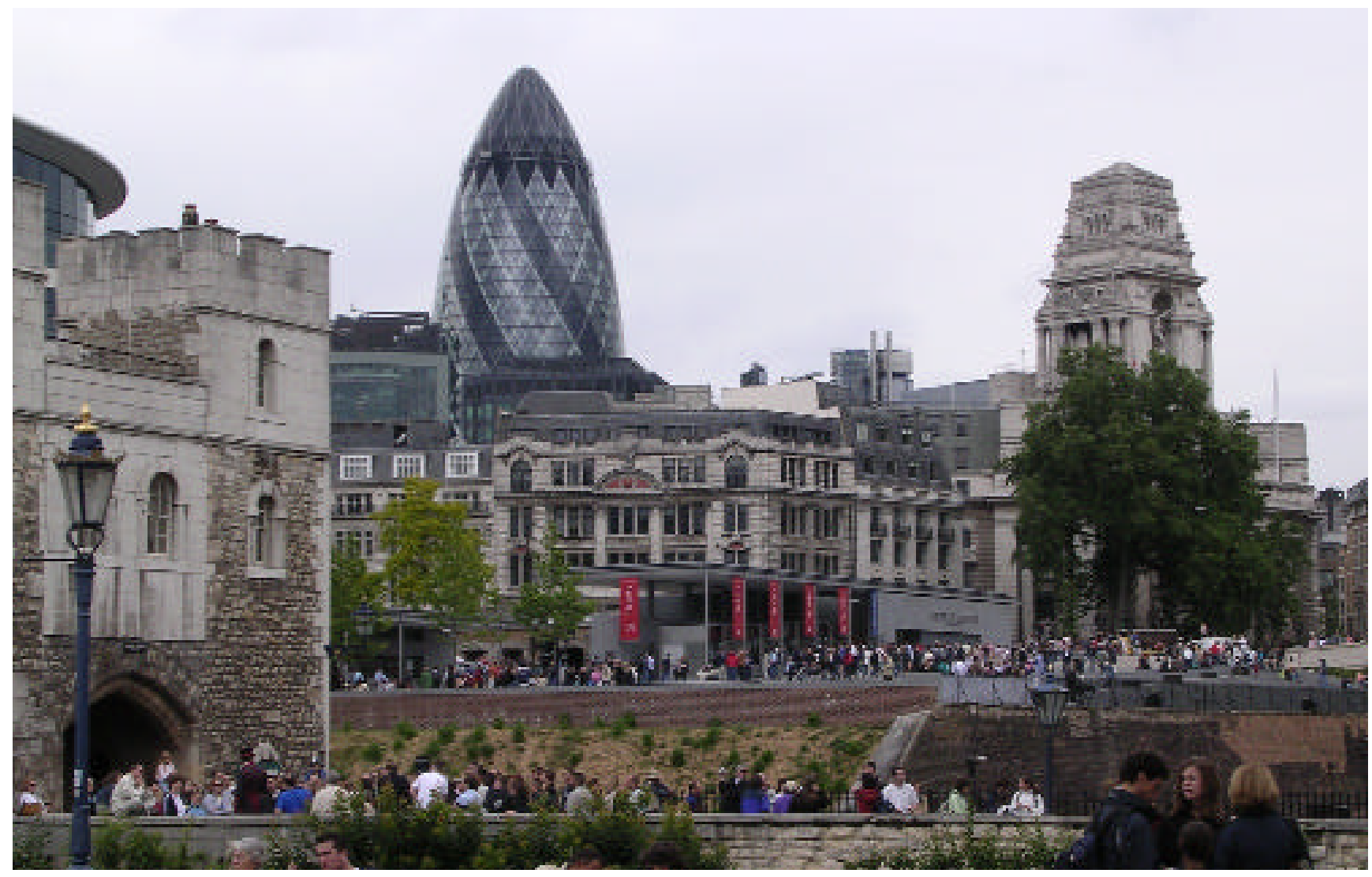

10

tificables. Si bien con el dinero que me cuesta un piso puedo comprar cinco coches, ¿a quién le resultan creibles equivalencias como éstas?

1. el valor estético de Las Meninas es igual que la suma de los valores estéticos de La fragua de Vulcano más Las Hilanderas.

2. la catedral de Santiago es tres veces más bella que la catedral de Burgos.

3. el valor histórico y cultural del yacimiento de Atapuerca es treinta veces mayor que el de las Cuevas de Altamira.

Los bienes culturales son objetos que encarnan valores simbólicos que no son cuantificables monetariamente ni son comprensibles al margen de una serie de discursos que son los que les otorgan su valor.

Un fragmento de cráneo de Atapuerca "vale" porque existe una ciencia que es la Paleontología. Una tela pintada "vale" porque creemos que existe la pintura, que es un arte, y que ese arte posee contenidos intelectuales y valores estéticos. Las viejas columnas y los restos arquitectónicos fueron sistemáticamente reutilizados a lo largo de la historia precisamente porque se les otorgaba valor económico. Nosotros no destruimos la Acrópolis de Atenas porque posee "valor artístico y simbólico" ¿Qué valor económico tendría la colina de la Acrópolis si se reurbanizase (ténganse en cuenta las vistas)?

No es este el lugar para volver a indicar que la ideología del "mercado de los bienes culturales" forma parte de un proceso de trivialización de la propia cultura, que está unido al desarrollo de unas ideologías políticas que pretenden justificar la omnipresencia del mercado y la transformación del ciudadano en mero consumidor que dedica la mayor parte de sus energías a llevar a cabo cálculos de costes y beneficios (véase "Sobre el buen uso de los monumentos arqueológicos"). Costes y beneficios que sólo sirven cuando existe el dinero de por medio, pero que ni siquiera se podrían aplicar si pretendemos que el fin de la sociedad es distribuir beneficios y placeres a todos en la mayor cantidad posible. En realidad, ni siquiera serían cuantificables los placeres: ¿el placer que produce comerse tres merluzas es igual a un orgasmo? ¿escuchar la Novena Sinfonía de Beethoven produce el mismo placer que escuchar treinta canciones country?

Agradecimiento: El texto "Sobre el buen uso de los monumentos arqueológicos" fue originalmente publicado en la revista Genon, vol. 20, núm. 1, 2002, pp. 1132. Agradecemos a esta revista la colaboración para su publicación en $\mathrm{PH}$. 